Vol. 44, N. 2 : pp. 185 - 189, June, 2001

ISSN 1516-8913 Printed in Brazil

\title{
Alleviating Soil Acidity Through Plant Organic Compounds
}

\author{
Anderson R. Meda, Marcelo E. Cassiolato, Marcos A. Pavan* and Mário Miyazawa \\ Instituto Agronômico do Paraná (IAPAR), Caixa Postal 481, CEP 86001-970, Londrina - PR, Brasil
}

\begin{abstract}
A laboratory experiment was conducted to evaluate the effects of water soluble plant extracts on soil acidity. The plant materials were: black oat, oil seed radish, white and blue lupin, gray and dwarf mucuna, Crotalaria spectabilis and C. breviflora, millet, pigeon pea, star grass, mato grosso grass, coffee leaves, sugar cane leaves, rice straw, and wheat straw. Plant extracts were added on soil surface in a PVC soil column at a rate of $1.0 \mathrm{ml} \mathrm{min}$ ${ }^{1}$. Both soil and drainage water were analyzed for $\mathrm{pH}, \mathrm{Ca}, \mathrm{Al}$, and $\mathrm{K}$. Plant extracts applied on the soil surface increased soil $\mathrm{pH}$, exchangeable $\mathrm{Ca}_{e x}$ and $K_{e x}$ and decreased $A l_{e x}$. Oil seed radish, black oat, and blue lupin were the best and millet the worst materials to alleviate soil acidity. Oil seed radish markedly increased Al in the drainage water. Chemical changes were associated with the concentrations of basic cations in the plant extract: the higher the concentration the greater the effects in alleviating soil acidity.
\end{abstract}

Key words: Plant residue, organic material, leaching

\section{INTRODUCTION}

Soil acidity is an important limiting factor for crop production in Brazil. Several studies have shown that plant residues left on soil surface improve the fertility levels of acid soils (Miyazawa et al., 1985; Pocknee \& Summer, 1997; Santos, 1997; Meda et al., 1999). These authors found that Ca-containing low weight organic molecule was shown to play the major role in alleviating soil acidity. It is believed that low molecular weight organic acids are released into the soil from plant residues and cause great effect on acid soil chemistry: increasing soil $\mathrm{pH}$ and exchangeable $\mathrm{Ca}_{\mathrm{ex}}, \mathrm{Mg}_{\mathrm{ex}}$, and $\mathrm{K}_{\mathrm{ex}}$ and decreasing $\mathrm{Al}_{\mathrm{ex}}$.

Although these organic acids are considered to be short-lived in soils, their continual production makes their anions important in soil chemistry due to high input of organic carbon into the agricultural systems in Brazil (Calegari et al., 1993; Chaves et al., 1997). However, there has been no direct study comparing the effects of various plant organic compounds on acidity in the soil surface and subsurface. The objective of this study was to evaluate the effects of various plant extracts on soil acidity.

\section{MATERIALS AND METHODS}

Soil sampling: Acid soil sample was collected from the $0-20 \mathrm{~cm}$ horizon of an uncultivated red dark latosol (Oxisol). The soil sample was air dried and ground to pass through a $2 \mathrm{~mm}$ screen before being treated with plant extracts. Sub sample was analyzed and had an original $\mathrm{pHCaCl}_{2}$ value of 4.10; exchangeable $\mathrm{Al}, \mathrm{Ca}, \mathrm{Mg}$, and $\mathrm{K}$

\footnotetext{
${ }^{*}$ Author for correspondence
} 
contents of $11.1,3.70,1.70$ and $0.50 \mathrm{mmol} \mathrm{dm}{ }^{-3}$, respectively; total acidity $(\mathrm{H}+\mathrm{Al})$ of $62.0 \mathrm{mmol}$ $\mathrm{dm}^{-3}$; and total carbon content of $7.64 \mathrm{~g} \mathrm{~kg}^{-1}$. The clay, silt and sand contents were 27, 2, $71 \%$, respectively.

\section{Plant sampling:}

Plant materials were: black oat (Avena strigosa), oil seed radish (Raphanus sativus), white lupin (Lupinus albus), blue lupin (Lupinus angustifolius), gray mucuna (Stizolobium cinereum), dwarf mucuna (Stizolobium deeringianum), Crotalaria spectabilis, Crotalaria breviflora, millet (Pennisetum typhoides), and pigeon pea (Cajanus cajan) collected at flowering stage; mato grosso grass (Paspalum notatum), star grass (Cynodon nlenfuensis), coffee leaves (Coffea arabica), and sugar cane leaves (Saccharum officinarum) collected during vegetative stage; and rice straw (Oryza sativa) and wheat straw (Triticum aestivum) collected after grain's harvest. Plant materials were dried at $65^{\circ} \mathrm{C}$ during $48 \mathrm{~h}$, ground to pass $1 \mathrm{~mm}$ sieve, and stored in plastic bags.

Plant extract: Water plant extracts were obtained by the following procedure: $3 \mathrm{~g}$ of dried plant material (equivalent to $10 \mathrm{t} \mathrm{ha}^{-1}$ ) was added to 150 $\mathrm{ml}$ of water (equivalent to 1 porous volume), shaken for $8 \mathrm{~h}$ and filtrated. Sub sample of the plant extract was used for chemical analysis (Table 1).

Experimental procedure: Untreated soil sample was transferred to PVC column $(25 \mathrm{~cm}$ high $\mathrm{x} 4$ $\mathrm{cm}$ diameter) and compacted to a homogeneous bulk density (mean $1 \mathrm{~g} \mathrm{~cm}^{-3}$ ) corresponding to natural condition. Plant extract solution was added on the soil surface. Then, deionized water was added in amount equivalent to three porous volume $(\mathrm{pV})$. Both, plant extract and water were added at a rate of $1.0 \mathrm{ml} \mathrm{min}{ }^{-1}$. Drainage solution was collected and analyzed for $\mathrm{pH}_{\mathrm{d}}, \mathrm{Al}_{\mathrm{d}}, \mathrm{Ca}_{\mathrm{d}}$, and $\mathrm{K}_{\mathrm{d}}$. Soil samples were taken at 0-5, 5-10, 10-15, 15-20, and 20-25 cm depth, air dried, ground to pass $2 \mathrm{~mm}$ sieve, and analyzed for $\mathrm{pH}$ and exchangeable $\mathrm{Al}_{\mathrm{ex}}, \mathrm{Ca}_{\mathrm{ex}}$, and $\mathrm{K}_{\mathrm{ex}}$. The soil $\mathrm{pH}$ was determined in $0.01 \mathrm{~mol} \mathrm{\textrm {L } ^ { - 1 }} \mathrm{CaCl}_{2}$ suspension (1:2.5 soil:solution ratio) after shaking for $1 \mathrm{~h} ; \mathrm{Al}_{\mathrm{ex}}$ and $\mathrm{Ca}_{\mathrm{ex}}$ were extracted with $\mathrm{KCl} 1.0 \mathrm{~mol} \mathrm{~L}^{-1}$ solution in a 1:10 soil:solution ratio and 10 minutes shaking time. Al was determined by titration with standardized $0.015 \mathrm{~mol} \mathrm{~L}^{-1} \mathrm{NaOH}$ solution using bromotymol blue indicator and $\mathrm{Ca}$ by atomic absorption spectroscopy. $\mathrm{K}_{\mathrm{ex}}$ was extracted with Mehlich solution $\left(0.05 \mathrm{~mol} \mathrm{~L}^{-1} \mathrm{HCl}\right.$ $+0.025 \mathrm{~mol} \mathrm{~L}^{-1} \mathrm{H}_{2} \mathrm{SO}_{4}$ ) and determined by flame photometry.

\section{RESULTS AND DISCUSSION}

Table 1 shows the chemical analysis of the plant extracts. As expected, there was a large range in the chemical composition. All plant extracts presented a $\mathrm{pH}>5.0$. Oil seed radish and blue lupin presented the highest $\mathrm{Ca}$ concentration. Black oat, Crotalaria spectabilis, C. breviflora, and oil seed radish presented the highest $\mathrm{K}$ concentration.

Table 1 - Chemical analysis of the plant extracts.

\begin{tabular}{lcccc}
\hline Plant material & \multicolumn{4}{c}{ Basic cations $\left(\mathrm{mg} \mathrm{dm}^{-3}\right)$} \\
\cline { 3 - 5 } & $\mathrm{pH}$ & $\mathrm{Ca}$ & $\mathrm{Mg}$ & $\mathrm{K}$ \\
\hline Black oat & 6.1 & 41.4 & 23.0 & 812.8 \\
Oil seed radish & 5.6 & 299.5 & 46.0 & 601.2 \\
White lupin & 5.9 & 38.6 & 21.0 & 260.0 \\
Blue lupin & 6.4 & 235.8 & 73.1 & 380.0 \\
Mato Grosso & 5.3 & 26.8 & 30.9 & 189.8 \\
Coffee leaves & 5.3 & 62.3 & 89.5 & 295.2 \\
Star grass & 5.8 & 46.8 & 31.2 & 430.6 \\
Sugar cane & 5.8 & 28.0 & 21.7 & 252.2 \\
Gray mucuna & 6.4 & 9.5 & 16.2 & 317.0 \\
Dwarf mucuna & 6.6 & 11.4 & 13.9 & 526.4 \\
C. spectabilis & 6.7 & 67.1 & 31.9 & 758.2 \\
C. breviflora & 7.0 & 48.4 & 42.1 & 704.8 \\
Millet & 5.7 & 2.6 & 63.2 & 38.0 \\
Pigeon pea & 5.5 & 14.7 & 26.1 & 130.0 \\
Rice straw & 5.8 & 2.6 & 20.0 & 360.0 \\
Wheat straw & 5.4 & 6.4 & 5.50 & 360.0 \\
\hline
\end{tabular}

Plant extract added on the soil surface changed the chemical composition of the soil profile, increasing $\mathrm{pH}$ (Figure 1), $\mathrm{Ca}_{\mathrm{ex}}$ (Figure 2), and $\mathrm{K}_{\mathrm{ex}}$ (Figure 3), and decreasing $\mathrm{Al}_{\mathrm{ex}}$ (Figure 4). For simplicity, these figures presented the effects of control, the most, the intermediate, and the least efficient plant material. The other extracts were classified among them. Blue lupin was the best material to increase soil $\mathrm{pH}$. The effects of oil seed radish and black oat on pHs were the same as blue lupin (data not shown). Millet extract was the least efficient, showing the same $\mathrm{pHs}$ as the unamended soil profile. These results suggested that where organic strategy is adopted, the following reaction illustrate the increase in $\mathrm{pH}$ : 


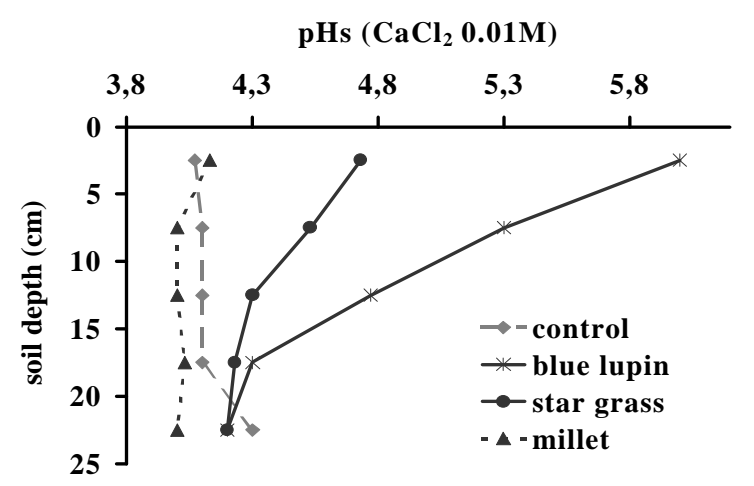

Figure 1 - Effects of plant materials on pHs.

$$
\mathrm{L}^{-1 / 2} \mathrm{Ca}^{++}+\mathrm{H}^{+} \rightarrow \mathrm{L}^{-} \mathrm{H}^{+}+1 / 2 \mathrm{Ca}^{++}
$$

Were $\mathrm{L}=$ organic ligant

Reaction (1) decreased $\mathrm{H}^{+}$ion and increased $\mathrm{Ca}^{++}$ ion in soil solution, resulting an increase in soil $\mathrm{pH}$.

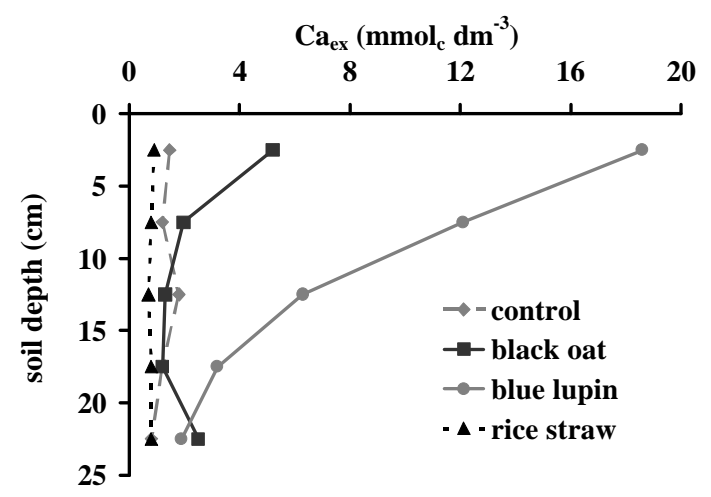

Figure 2 - Effects of plant materials on $\mathrm{Ca}_{\mathrm{ex}}$.

The majority of plant materials increased $\mathrm{Ca}_{\mathrm{ex}}$ in the top surface (Figure 2). Blue lupin was the best and rice straw the worst material in improving $\mathrm{Ca}_{\mathrm{ex}}$. Star grass and sugar cane leaves were the best material to carry $\mathrm{Ca}$ ions deeper in the soil profile (data not shown). The possible reactions that illustrated the increase in $\mathrm{Ca}_{\mathrm{ex}}(2)$ and the Caorganic mobile (3ab) were the following, respectively:

$\mathrm{X}^{--}+\mathrm{Ca}_{\mathrm{s}} \rightarrow \mathrm{X}^{--} \mathrm{Ca}_{\mathrm{ex}}^{++}$

Were $\mathrm{X}=$ soil exchangeable site and $\mathrm{s}=$ soluble ion.

$$
\begin{aligned}
& \mathrm{L}^{--}+\mathrm{Ca}_{\mathrm{s}}^{++} \rightarrow\left[\mathrm{L}^{--} \mathrm{Ca}^{++}\right]_{\mathrm{s}}^{0} \text { and/or } \\
& \mathrm{L}^{--}+\mathrm{Ca}_{\mathrm{s}}^{++} \rightarrow\left[\mathrm{L}^{-} \mathrm{Ca}^{++}\right]_{\mathrm{s}}^{+}
\end{aligned}
$$

Reactions (3a) and (3b) favored the mobility of $\mathrm{Ca}$ in soil due to ion pair formation. These reactions decreased the valence of $\mathrm{Ca}$ in solution. All plant materials increased $\mathrm{K}_{\mathrm{ex}}$ in relation to control (Figure 3). Crotalaria spectabilis and black oat showed the best effect on $\mathrm{K}_{\mathrm{ex}}$ and millet the worst effect on $\mathrm{K}_{\mathrm{ex}}$. The increase in $\mathrm{K}_{\mathrm{ex}}$ was due to increase in the $\mathrm{pH}$-dependent exchangeable site. The possible reaction was:

$\mathrm{X}^{-}+\mathrm{K}_{\mathrm{s}}^{+} \rightarrow \mathrm{X}^{-} \mathrm{K}_{\mathrm{ex}}^{+}$

(4)

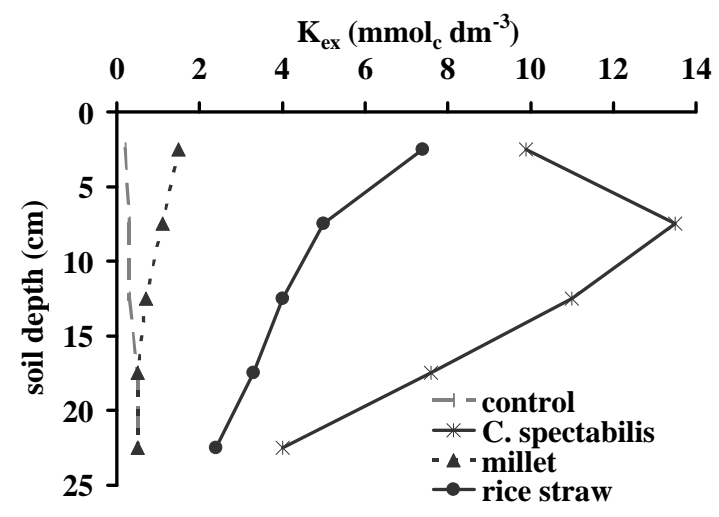

Figure 3 - Effects of plant materials on $\mathrm{K}_{\mathrm{ex}}$.

All plant extracts showed the capacity to reduce $\mathrm{Al}_{\mathrm{ex}}$ in the soil profile (Figure 4). Blue lupin, black oat, and oil seed radish presented the best effect in reducing $\mathrm{Al}_{\mathrm{ex}}$ in the top $0-10 \mathrm{~cm}$. Millet showed the worst capacity in reducing $\mathrm{Al}_{\mathrm{ex}}$. Possible mechanisms previously proposed to explain decreases in $\mathrm{Al}_{\mathrm{ex}}$ after organic matter addition include: (i) adsorption of $\mathrm{Al}^{3+}$ ions on to the surface of the added organic compounds and (ii) precipitation of $\mathrm{Al}^{3+}$ due to increase in soil $\mathrm{pH}$ (Miyazawa et al., 1993). The possible reactions were:

$$
\begin{aligned}
& \mathrm{L}^{-}+1 / 3 \mathrm{Al}^{+++} \rightarrow\left[\mathrm{L}^{-} 1 / 3 \mathrm{Al}^{+++}\right]^{0} \\
& \mathrm{Al}^{+++}+3 \mathrm{OH}^{-} \rightarrow \mathrm{Al}(\mathrm{OH})_{3}{ }^{0}
\end{aligned}
$$




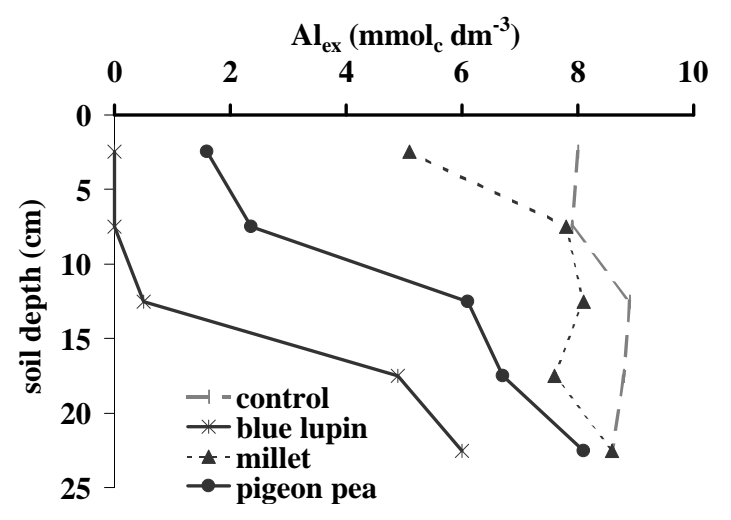

Figure 4 - Effects of plant materials on $\mathrm{Al}_{\mathrm{ex}}$.

Plant extracts added on soil surface changed the chemical composition of the drainage water (Figures 5, 6, 7 and 8). The concentrations of $\mathrm{Ca}_{\mathrm{d}}$,

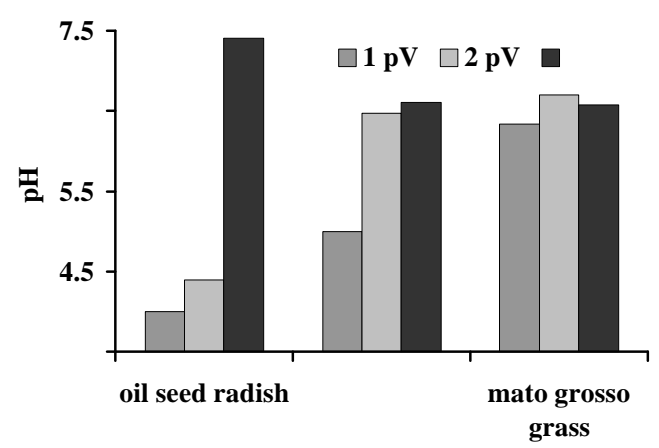

Figure 5 - Effects of plant materials on drainage water $\mathrm{pH}_{\mathrm{d}}$.

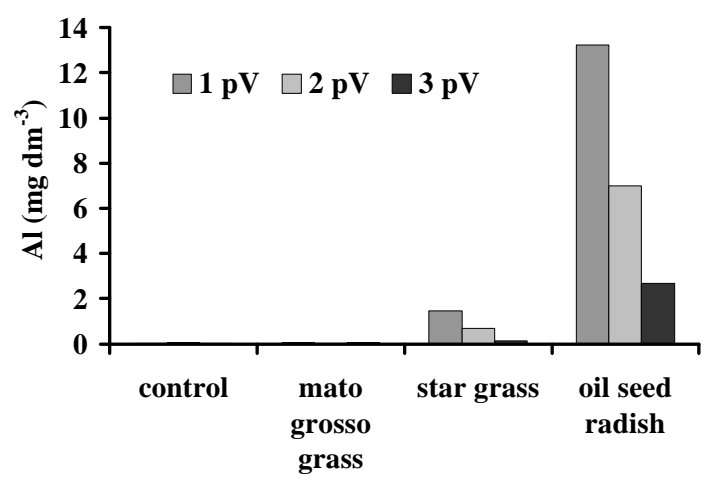

Figure 6 - Effects of plant materials on drainage water $\mathrm{Al}_{\mathrm{d}}$.

$\mathrm{K}_{\mathrm{d}}$ and $\mathrm{Al}_{\mathrm{d}}$ decreased and $\mathrm{pH}_{\mathrm{d}}$ increased with increasing $\mathrm{pV}$. These effects were due to dilution factor. Oil seed radish, black oat and wheat straw caused the greatest decrease in $\mathrm{pH}_{\mathrm{d}}$, and coffee leaves and mato grosso grass the greatest increase in $\mathrm{pH}_{\mathrm{d}}$ as compared with control (Figure 5).

Oil seed radish showed the highest capacity as Alcarrier from the $0-25 \mathrm{~cm}$ profile (Figure 6). This result suggest that water organic compounds from oil seed radish has high capacity in complexing $\mathrm{Al}$ in soil solution. Star grass extract was the most efficient in moving $\mathrm{Ca}$ out of the soil column (Figure 7).

The results obtained in the present study allowed to conclude that the chemical changes in soil and in drainage solution were associated with the concentration of basic cations in the plant extract (Table 1). The higher the cation concentration in the plant residue the greater the effect on the chemistry of the acid soils.

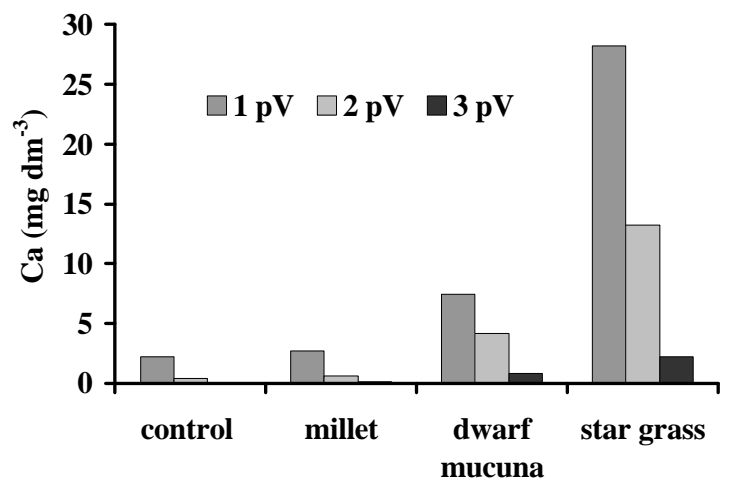

Figure 7 - Effects of plant materials on drainage water $\mathrm{Ca}_{\mathrm{d}}$.

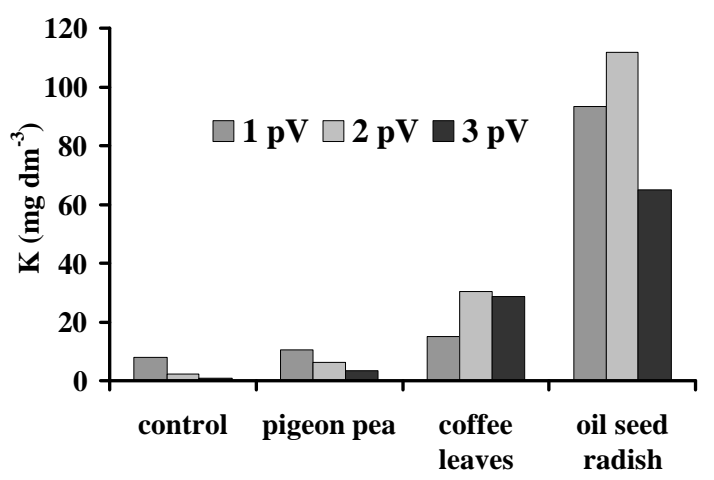

Figure 8 - Effects of plant materials on drainage water $\mathrm{K}_{\mathrm{d}}$.

\section{ACKNOWLEDGEMENTS}

Anderson R. Meda and Marcelo E. Cassiolato thank to $\mathrm{CNPq}$ for the award of the scientific initiation scholarship. 


\section{RESUMO}

Foram conduzidos experimentos de laboratórios para avaliar os efeitos de extratos de plantas solúveis em água na acidez do solo. Os materiais de plantas foram: aveia preta, nabo, tremoço branco e azul, mucuna cinza e anã, Crotalaria spectabilis e C. breviflora, milheto, guandu, grama estrela, grama mato grosso, folhas de café, folhas de cana-de-açúcar, palhada de arroz e palhada de trigo. Foi utilizado o seguinte procedimento para o extrato da planta solúvel em água: pesar $3 \mathrm{~g}$ de material de planta, adicionar $150 \mathrm{ml}$ de água, agitar por $8 \mathrm{~h}$ e filtrar. Os extratos de plantas foram adicionados na superfície do solo em uma coluna de PVC $\left(1 \mathrm{ml} \mathrm{min}{ }^{-1}\right)$. Após, adicionou-se água deionizada em quantidade equivalente a três volumes de poros. Os extratos de plantas aumentaram o $\mathrm{pH}$, Ca e $\mathrm{K}$ trocável e diminuíram Al. Nabo, aveia preta e tremoço azul foram os melhores e milheto o pior material para amenizar a acidez do solo. Nabo aumentou Al na água de drenagem. As alterações químicas foram associadas com as concentrações de

básicos nos extratos de plantas: quanto maior a concentração maior o efeito na

acidez do solo.

\section{REFERENCES}

Calegari, A.; Mondardo, M.; Bulisani, E.A.; Wildner, L.D.P.; Costa, M.B.B. da; Alcântara, P.B.; Miyazaka, S. and Amado, T.J.C. (1993), Adubação Verde no Sul do Brasil. Assessoria de Serviços a Projetos em Agricultura Alternativa, Rio de Janeiro, 95-101

Chaves, J. C. D.; Pavan, M. A. and Calegari, A. (1997), Input of dry matter and nutrients to the soil from cover plants cultivated between rows of perennial crops and their effects on soil reaction. Arq. Biol. Tecnol., 40, 47-55

Meda, A. R.; Cassiolato, M. E.; Miyazawa, M. and Pavan, M. A. (1999), Plant extracts to improve acid soil chemistry. Congresso Lationamericano de Ciência do Solo. Temuco Pucon 1999. Anais. Temuco Pucon, Sociedade Latino Americana de Ciência do Solo., 360p

Miyazawa, M.; Pavan, M. A. and Calegari, A. (1985), Efeito de material vegetal na acidez do solo. Rev. Bras. Ci. Sol., 17, 411-416

Pocknee, S. and Sumner, M. E. (1997), Cation and nitrogen contents of organic matter determine its soil liming potential. Soil Sci. Soc. Am. J., 61, 86-92

Santos, J. C. F. (1997), Mobilização de cálcio e alumínio em solos ácidos por compostos orgânicos hidrossolúveis de resíduos vegetais. Tese de Doutoramento, Centro de Energia na Agricultura, Universidade de São Paulo, Piracicaba, Brasil.

Received: October 13, 1999; Revised: July 03, 2000; Accepted: September 01, 2000. 